Members of the conference had the privilege of attending meetings of the Linnean, Zoological, and Entomological Societies, as well as the Staff Conversazione at the Natural History Museum. These gatherings, in addition to the three whole-day excursions to Rothamsted, Oxford, and Cambridge, gave welcome opportunity for informal discussion and pleasant social intercourse. Much gratification was. felt and expressed at the presence for the first two days of Dr. L. O. Howard, Entomologist of the U.S. Department of Agriculture. His brief, pointed remarks at some of the discussions were much appreciated; he deplored some recent attempts to destroy "entomology" as a specific economic subject by dividing its subject-matter between "parasitology" and "phytopathology." All who participated in the conference appreciated the untiring efforts of Dr. G. A. K. Marshall and Dr. S. A. Neave, of the Imperial Bureau, who before and during the meetings did their utmost for the success of the gathering.

On the evening of the closing day the members of the conference were entertained to dinner at Lancaster House by H.M. Government, Viscount Harcourt presiding. Thus was pleasantly and fittingly demonstrated the increasing recognition of the importance of the study and practice of science in relation to the interests and industries of the Empire.

G. H. C.

\section{The Selous Memorial at the Natural History Museum.}

THE movement started in IgI7 to perpetuate the memory of the late Capt. F. C. Selous, D.S.O., by a national memorial achieved its aim on Thursday, June Io, when Mr. Edward North Buxton, vice-chairman of the Memorial Committee, himself a great hunter in his day, in the unavoidable absence of the chairman, the Right Hon. E. S. Montagu, M.P., unveiled at the Natural History Museum, South Kensington, a bronze bust of Selous-the work of Mr. W. R. Colton, R.A.-before a distinguished and representative gathering.

The bust is mounted in a niche of grey granite from the Matoppo Hills, the burial-place of Cecil Rhodes and Sir Starr Jameson, and is the gift of the Union Government of South Africa. It was brought to this country by the Union Castle Line free of all charges. Below the bust is a bas-relief, also in bronze, depicting a lion and lioness, and in the distance an elephant, a situtunga, and other big-game animals, symbolical of the interests of the great sportsman and explorer. The granite bears the inscription: "Captain Frederick C. Selous, D.S.O., hunter, explorer, and naturalist. Born I853. Killed in action at Beho-Beho, German East Africa, 4. i. I9I7."

Mr. Buxton in his speech referred to the qualities of Selous which had endeared him to so many friends, and summarised these when he said that "Selous was a great hunter, and a still greater gentleman." On behalf of the committee he asked Viscount Grey of Fallodon, K.G., and the other trustees of the museum to accept the memorial and to preserve it in the museum for all posterity.

In his reply Lord Grey stated that in the museum, which was a national institution, this national memorial would be kept and honoured as a memorial to one who was a great explorer, a great traveller, a great hunter, and, besides that, a most brave and single-minded and attractive character.

The King sent a message to the effect that he felt that no more appropriate place than the Natural History Museum could be selected for a memorial to Capt. F. C. Selous.

NO. 2642 , VOL. IO5]
It is indeed in the titness of things that this memorial should have found a permanent place in the museum; for, next to his own home, there was no place in England which more attracted Selous than the museum, and when he was in this country he seldom kept away from it for more than a week; sometimes he was a daily visitor.

A guard of honour composed of officers and men of the Legion of Frontiersmen, many of whom had served with Selous in East Africa, and a detachment of the Kensington Division of Boy Scouts were present.

The response to the committee's appeal for funds for the memorial has been so widespread and generous that they have been able to provide a sum of monev for the foundation of a substantial Selous scholarship at his old school, Rugby, on the basis that preference will be given at each election to the sons of officers who have fallen in the war, and in this connection

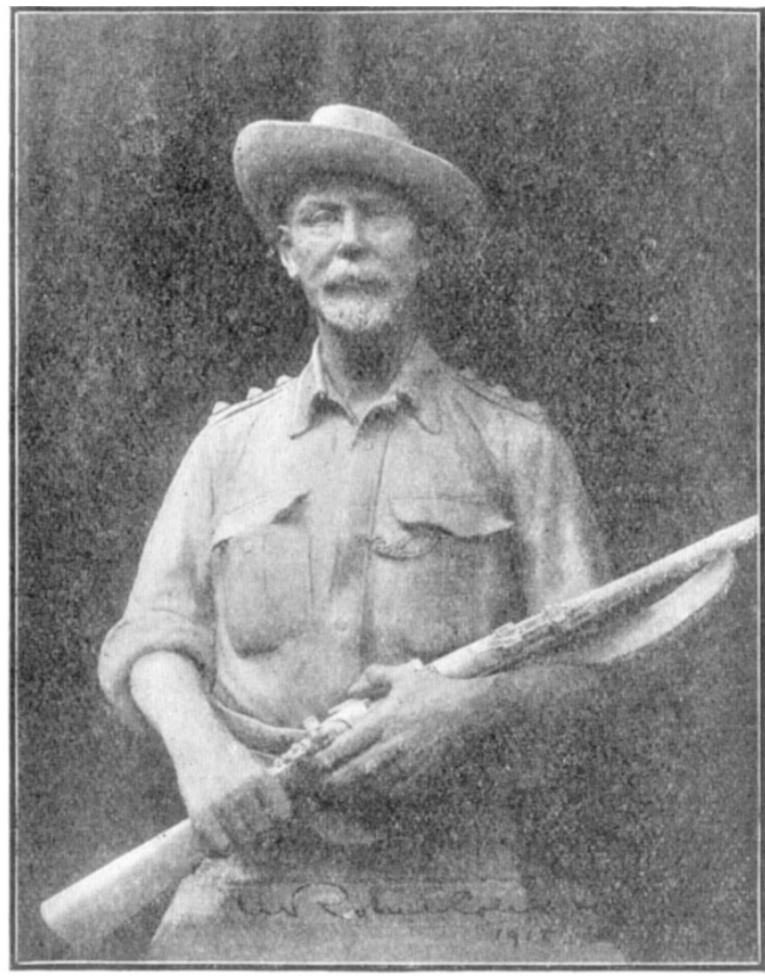

The Selous Memorial Bust in the Natural History Museum. On the right hand side of the memorial, not shown here, is the following inscrip tion :- "Captain Frederick C. Selous, D.S.O., hunter, explorer, and naturalist. Born 1853 , Killed in action at Beho-Beho, German East Africa, 4.i.rg17."

it is with special satisfaction that we learn that in the examination for the scholarship a love and know. ledge of natural history on the part of the candidate will be the deciding factor.

A few words may be said respecting Mrs. Selous's gift to the nation of her husband's splendid collection of big-game trophies and of birds' eggs, a gift for which Viscount Grey, on behalf of the trustees, conveyed to the donor his warm thanks, and at the same time expressed his high appreciation of its value and importance.

The collections have now been received at the Natural History Museum, and the big-game specimens are in course of being catalogued by $\mathrm{Mr}$. Guy Dollman. We understand that it is the intention of the trustees to publish this catalogue, a work which cannot fail 
to be of abiding interest to naturalists and sportsmen. The collection consists of $55^{\circ}$ specimens-the greater part from South and East Africa-of splendid heads. It also includes nineteen magnificent lionskins and a skull of the South African white rhinoceros-an extinct species-with exceptionally fine horns.

The collection of birds' eggs consists of 7oIo specimens obtained in Great Britain, Europe, and Asia Minor. The great feature of the collection is that Capt. Selous personally took every egg from the nest himself. He would never accept any egg or clutch of eggs offered to him by a friend, nor would he purchase one from a dealer.

At the summons of a friend announcing the discovery of some rare bird's nest he would often travel very long distances, e.g. from one end of the British Isles to the other, in order that he might personally identifv the parent birds and personally take the eqgs from the nest. For this reason, no less than for the amazing neatness and methodical care with which it was arranged, to say nothing of its comprehensive range, the collection is a particularly valuable one.

\section{University and Educational Intelligence.}

Birmingham.--On the advice of Sir John Cadman, whose appointment as a technical adviser to the Government on matters relating to coal and petroleum is announced, the department of mining is to be reorganised and extended. In addition to the new professor of mining there is to be an assistant-professor of petroleum technologv. It is hoped that Sir John Cadman will still retain some connection with the faculty of science.

Prof. F. W. Burstall has been elected dean of the faculty of science, to succeed Sir John Cadman.

CAMBRIDGE.-As briefly announced last week, a scheme for endowing a school of biochemistry has been approved by the High Court of Justice, and has now been submitted to the University by Sir Jeremiah Colman, Bart., on behalf of the trustees of the late Sir William Dunn, Bart. The residuary estate of Sir William Dunn was left in trust for certain charitable purposes, including the alleviation of human suffering. The trustees propose, with that object in view, to encourage and endow with the substantial sum of $160,000 l$. the study of biochemistry, one of the fundamental sciences of medicine, the progress of which is essential to the advance of medical knowledge. Having regard to the fact that the study of bio chemistry in this country had its first beginnings in Cambridge, and is at present being carried on there without endowment under Prof. Gowland Hopkins, the trustees offer the University $6_{5}, 000 l$. to found the Sir William Dunn School of Biochemistry. Of this sum they allot $25,000 l$. to endow a professorship and 10;00ol. to endow a readership in biochemistry, the balance to be used in erecting and equipping an institute of biochemistry and in providing funds for its maintenance and upkeep and an endowment for research work.

This munificent benefaction is a most pleasing tribute to the work of Prof. Hopkins and his colleagues.

Dr. T. G. Adami, Vice-Chancellor of Liverpool University, has been elected honorary fellow of Jesus College.

Mr. J. E. Littlewood, Trinity College, has been appointed Cayley lecturer in mathematics, and $\mathrm{Mr}$. I. H. Grace, Peterhouse, has been re-appointed University lecturer in mathematics.

The Special Board for Mathematics has recommended the substitution of thermodynamics for elementary optics in Schedule A of Part II. of the Mathematical Tripos.

In connection with the coming meeting of the British Medical Association at Cambridge, honorary degrees are proposed for the Master of Pembroke, Sir T. Clifford Allbutt, Jules Bordet, A. Calmette, H. Cushing, S. Flexner, Piero Giacosa, Major-Gen. Gorgas, Sir George Makins, Sir Patrick Manson, and Sir Norman Moore.

LIVERPOOL.-The council of the University has appointed $\mathrm{Mr}$. T. R. Wilton as lecturer in dock and harbour engineering, with the title of associateprofessor. Mr. Wilton is closely connected with the Liverpool Engineering Society, and has done valuable work for that body as hon. secretary-a position he has held since 190\%. He has been for some years. special lecturer in dock and harbour construction at the University, has carried out important investigations on the movement of sand and currents, and has also taken observations of a practical nature on the Mersey.

Mr. H. Richardson, of the Municipal College of Technology, Manchester, has been appointed principal of the Bradford Technical College in succession to Prof. W. M. Gardner.

THE Ministry of Agriculture and Fisheries is open to receive until July $I_{5}$ nominations for a limited number of research scholarships in agricultural science, each tenable for two years, and of the annual value of $200 l$. Candidates must be graduates with honours in science of British universities, with evidence of high proficiency in subjects having a direct bearing on agriculture, and be nominated by a professor or lecturer of a university or college. Nomination forms are obtainable from the General Secretary of the Ministry, 72 Victoria Street, S.W.r.

THe Library Association Record for May contains a paper on "Technical Libraries and Intelligence" by Major W. E. Simnet, and also an article on "The Technical Library" by Mr. R. Borlase Matthews. Mr. Matthews lays stress on the necessity for making the most recent publications immediately available for reference, and discusses the various ways in which a technical library can be made accessible to readers. Major Simnet, taking the subject of engineering as an example, points out that there are at present in London several libraries containing books and periodicals relating to engineering, and that this involves much overlapping which might be avoided by amalgamation. $\mathrm{He}$ also refers to the Transport Library to be formed by the Ministry of Transport. Such a library would be devoted to all aspects and methods of transportation. The importance of an index of technical literature, possibly on the lines of the International Catalogue of Scientific Literature, is carefully explained by Major Simnet, who recommends a combination of indexing and abstracting. At the same time he finds that papers on technical subjects become out of date much sooner than papers on purely scientific topics, so that it is less necessary to preserve all titles of technical papers in a permanent index. Major Simnet gives an account of the Technical Review, established since the armistice to continue the work of the Technical Supplement, published in 1918 under the auspices of the War Office. As a further contribution to the indexing of technology, the Library. Association Record for Mav, I920, contains a subject-index to papers published in $1917^{-19}$ on fuel, including gas and petroleum. The list is prepared by the editors of the "Subject Index of Periodicals," and is an example of the thoroughness which their work always exhibits. 